\title{
The Analysis of Surabaya Muzaki's Preference for Zakat Payment through Zakat Digital Method
}

\author{
Deasy Tantriana and Lilik Rahmawati \\ State Islamic University of Sunan Ampel Surabaya \\ Paper to be presented at International Conference of Zakat (ICONZ) 2018 \\ 15-16 November, Universitas Gadjah Mada, Yogyakarta, Indonesia
}

\begin{abstract}
The research aims to identify the level of Surabaya people's preference in determining way of Zakat (payment made annually under Islamic law on certain kinds of property and used for charitable and religious purposes, one of the Five Pillars of Islam) payment in the digital era in which Muzaki (one obliged to pay Zakat) no need to come to particular institution in charge of Zakat management but they can do it digitally. Many digital zakat applications show up in Indonesia including that of BAZNAS, those issued by other institutions such as Amil Zakat institutions, and even the one issued by E-commerce institutions. Surabaya as the second largest city in Indonesia can depict to what extent urban people use digital application for Zakat payment, or to what extent they remain using conventional methods. This is a descriptive study which deployed frequency distribution analysis, cross tabulation, logit, multi-nominal logit and qualitative description.

For data feasibility, this study involved the people of Surabaya as the research population especially those with obligation of zakat payment. The research results suggest how effective the digital zakat payment method has been carried out. Based on the analysis results, it was found that the variable of zakat knowledge, the level of certainty and the level of satisfaction had a significant effect on the preferences of muzaki for zakat payment. The recommendation to submit is that policy makers should frequently promote the use of digital zakat so that more people will likely know the digital zakat payment method.
\end{abstract}

Keywords: Preference, Surabaya Muzaki, Digital Zakat

\section{BACKGROUND}

Nowadays, the internet is the most widelyused information technology network. Thus, everyone relatively has easy access to it. This particular technology can easily innovate and develop in accordance with the society's development. In addition, almost all human needs are easily acccessible to the internet. That way, The internet becomes the most needed medium to date. Most fields of business and services growing rapidly make the most use of technological developments by providing online systems.

Hence, many zakat institutions are desperately in need of using online system.
Therefore, regulation No. 38/1999 about the Management of Zakat then renewed in 2011 with regulation No. 23/2011. The regulation stated that as Amil Zakat (BAZ) and Amil Zakat Institution (LAZ) must function to manage the people's zakat based on Islamic law, mandate, benefit, justice, legal certainty, integration, accountability, trustworthiness and accountability. ${ }^{1}$ Thus, to implement the principles, the use of online media comes as solution.

\footnotetext{
${ }^{1}$ http://baznas.ciamiskab.go.id/pengelolaan-zakatdalam-undang-undang-no-23-tahun-2011. Accessed on September 15, 2018
} 
At present, Muslims in Indonesia tend to make zakat payment and giving through online media. Thus, as it becomes the people's modern lifestyle, many zakat institutions in cooperation with start-up institutions provide zakat payment services online one of which is the one issued by LAZ Rumah Zakat. Furthermore, the CEO of Rumah Zakat, Nur Efendi once stated that in 2016 alone, the total donation of zakat through his institution was IDR 230 billions, and $70 \%$ percent are applied via non-cash payment by the donators. Recently, Rumah Zakat collaborates with some start-up institutions such as online shop Blibli.com, Elevania, and Tokopedia to provide zakat features. ${ }^{2}$ Moreover, LAZ comes up with another model such as IZI which provides zakat application through Zakatpedia.com. $^{3}$

Apart of enabling to increase the amount of zakat donations, making the most use of online media by both BAZ and LAZ enables to update zakat the collection, distribution, online zakat improvement, allowing people to make an zakat payment any time. People can even monitor the distribution of zakat through an online application already available. They can also monitor the financial reports of a particular zakat institution.

With the phenomenon of online zakat payments, the study of the effectiveness of digital zakat payments needs to be carried out. To identify the preference of muzaki in Surabaya in accordance with digital zakat also needs to endeavour, whether muzaki prefer to use digital zakat or implement a direct payments through amil zakat, mosques or other institutions. Through previous researches, no comprehensive study has been conducted especially to identify the effectiveness of digital zakat.

\footnotetext{
${ }^{2}$ http://www.pikiranrakyat.com/ekonomi/2017/05/16/trend-bayar-zakatsecara-online-bagaimana-hukumnya-401251. Accessed on September 16, 2018 ${ }^{3}$ http://IZI.or.id
}

\section{THEORETICAL BACKGROUND}

According the study conducted by Nurul Nadiah Ahmad, Mahlindayu Tarmidi, Izzatul Ussna Ridzwan, Masdiah Abdul Hamid, Rusli Abdul Roni (2014) of Universiti Tenaga Nasional, Malaysia, the use of digital technology, especially the Unified Theory of Acceptance and Use of Technology (UTAUT) models on zakat payment systems in zakat institutions in Selangor Malaysia was written in an article entitled "The Application of Unified Theory of Acceptance and Use of Technology (Predicting the Usage of EUT) Zakat Online System."

In addition, according to research conducted by Marliana Ekawati with the title "Understanding Behavior of Zakat Payment Methods: The Analysis of Muzakki In Malang City, Indonesia" mentioning that people decided to make the zakat payment through three methods such as mosque, Amil Zakat institution (LAZ) and Amil Zakat Agency (BAZ) which distribute the zakat directly to those who deserve it (the poor).

Furthermore, another paper entitled "Measurement model of corporate zakat collection in Malaysia: A test of diffusion on innovation theory" by MuhammadBashir Owolabi Yusuf of the Department of Economics, International Islamic University, Gombak, Malaysia focuses on the model of zakat collection in Malaysia by the Zakat Institution by adopting new theories.

Another study entitled "The Analysis of the Efficiency \& Effectiveness of Zakat Payroll System and Digital Zakat on the Receipt of Zakat on Baznas Period 2016-2017" and written by S Jamila from UIN Jakarta in 2018 indicated that payment of Payroll zakat is effective to increase the amount of zakat.

Whereas, according to the article of Wiradani (2013), muzakki's consideration to make zakat payments through Ash Shohwah Social Charity Foundation in Malang in 2012 deals with analysis 
technique factor which obtains eight factors of such as factors of service, place, people, distribution, process, motivation, responsiveness, and atmosphere with the factor of people works as the most dominant one.

Building E-Zakat application was the case study of LAZ conducted by Nanang Gunawan of Mercu Buana University in 2012. The study concluded that the online application of zakat, infaq and shadaqah run as expected. In addition, the online application of zakat, infaq and shadaqah of Manarul Amal Mosque Foundation in the same university also run well and even enable students to actively involve in charity as expected times and places.

"Preference" is the English word which means someone's selection of something, the right or chance to choose, or someone / something to be chosen (Soukhanove, 1992: 1428). Consumer's preference is someone's choice; likes or dislikes towards certain products (goods or services). Consumer's preference shows people's behaviour towards various products (goods or service) (Kotler, 1997). Whereas, Muzakki means every single person obliged to pay zakat for their property ownership which reaches a particular nishab and haul.

\section{Research Method}

This is a descriptive quantitative research using quantitative analysis with the use of frequency tables, logit and multinominal logit analysis. Multinominal logit analysis aims to observe the interrelationships among components of the study. Muslims in Surabaya specifically 100 samples of those with the obligation of zakat payment are involved as the research population.

\section{Operational Variables}

This study deal with two dependent variables which consist of dummy variable with the following descriptions:
1. Variables of zakat payment means if the respondent does not / has not paid zakat, the value then is " 0 " and "1" when the zakat payment has been made.

2. Variable of place to pay zakat of trade (business). It means that if the respondents make the zakat payment in BAZ / LAZ, the value then is " 0 ", and " 1 " if the zakat payments has been made in mosque. In addition, if the respondents have made a direct zakat, the value is " 2 ", and " 3 " if the zakat has been made through digital application.

\section{Free Variables}

To ensure the proportion of those who do not / have not paid zakat of trade, 3 independent variables will likely affect the dependent variable described as follows:

1. Knowledge of zakat means sufficient or insufficient information owned by muzakki of online zakat, the necessity of the payment of zakat fitri and zakat maal, and the socialization of online zakat.

2. Certainty concerns the method of zakat payment, whether or not online zakat has been made.

3. Level of satisfaction concerns the preference of online zakat or a direct zakat payment.

Surabaya is one selected metropolitan city due to its develepment of technology apparently used by urban people especially in relation to digital zakat. The study used non probability sampling, which no equal opportunity for each element or member of the population to be taken as sample. The number of samples was calculated based on the source of Roscoe (1975) quoted by Uma Sekaran (2006) about size of research sample determination which is minimally 100 respondents. The image below shows method used in the questionnaire analysis. 
Image 1. Theoretical Framework

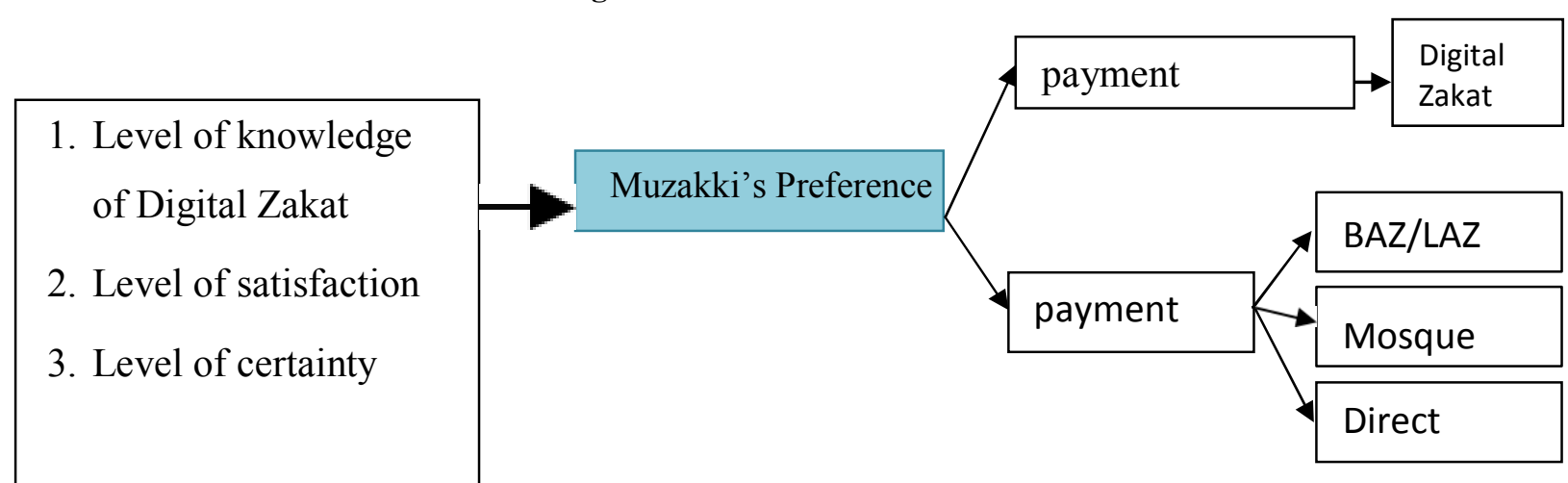

RESEARCH RESULT

Sex and Age of Respondents

Overall composition of questionnaire based on gender and zakat payment

Table 1. Respondents' List Based on Age

\begin{tabular}{|l|c|}
\hline \multicolumn{1}{|c|}{ Age } & Total \\
\hline $20-30$ Years & 26 \\
\hline $30-40$ Years & 48 \\
\hline $40-50$ Years & 17 \\
\hline $50-60$ Years & 9 \\
\hline$>70$ Years & 0 \\
\hline
\end{tabular}

indicated that, from the sample of respondents, $39.1 \%$ were women with 26 respondents paid monthly zakat maal regularly, and $73.9 \%$ paid annual zakat fitrah.

\section{Education}

Based on educational category, out of 100 respondents, no respondent $(0 \%)$ graduated from junior high school, $5 \%$ of them graduated from senior high school and $66.7 \%$ take Diploma / S1 degree. Above all, $29 \%$ of respondents have post-graduate degree. Thus, most respondents have Diploma / S1 degree with 66.7\%.

Table 2. Respondents' Educational Background

\begin{tabular}{|c|l|r|r|}
\hline No. & Level of Education & Total & Percentage (\%) \\
\hline 1 & SMP & 0 & $0 \%$ \\
\hline 2 & SMA/SMK & 5 & $4.1 \%$ \\
\hline 3 & Diploma/S1 & 66 & $66.7 \%$ \\
\hline 4 & S2/S3 & 29 & $29.2 \%$ \\
\hline 5 & Mention Others... & 0 & 0 \\
\hline
\end{tabular}

\section{Occupational Background}

Based on occupational background, out of 100 respondents, $45 \%$ of them work as civil servants (PNS), 15\% of them work at private sectors and $25 \%$ are self-employed, and the other $15 \%$ could be housewives.

Table 3. Respondents' Occupational Background

\begin{tabular}{|c|l|c|c|}
\hline No. & \multicolumn{1}{|c|}{ Occupation } & Amount & Percentage (\%) \\
\hline 1 & Civil Servant & 45 & $45 \%$ \\
\hline 2 & Worker of private sectors & 15 & $15 \%$ \\
\hline 3 & Self-employment & 25 & $25 \%$ \\
\hline 5 & Mention Others... & 15 & $15 \%$ \\
\hline
\end{tabular}




\section{RESULT AND CONCLUSION}

Based on the results of the likelihood test for model significance, the variable of knowledge of digital zakat, level of certainty and level of satisfaction can be included in the model as these variables are statistically significant at $\alpha=5 \%$. In other words, the variables can be used as independent variables in the multinominal model, the output can be further seen in table 4.59 below.

Table 4. Likelihood Test Result

\begin{tabular}{|l|r|r|r|r|}
\hline \multicolumn{1}{|c|}{ Effect } & $\begin{array}{l}-2 \text { Log Likelihood } \\
\text { of Reduced Model }\end{array}$ & \multicolumn{1}{c|}{$\begin{array}{c}\text { Chi- } \\
\text { Square }\end{array}$} & \multicolumn{1}{c|}{ df } & \multicolumn{1}{c|}{ Sig. } \\
\hline Intercept & $23,110(\mathrm{a})$ &, 000 & 0 &. \\
\hline PZD & 35,831 & 11,721 & 2 &, 004 \\
\hline SURE & 43,828 & 22,719 & 2 &, 000 \\
\hline KPS & 30,276 & 7,166 & 2 &, 023 \\
\hline
\end{tabular}

Source: SPSS-based primary Data Process

Based on Wald's test all variables are individually statistically significant. One of the consequences of all significant independent variables coefficients is that the interval trust of the odds ratio is relatively not wide.

Table 5. Assessment Result Equation Parameters 3.14

\begin{tabular}{|l|l|r|r|r|r|}
\hline Zakat Payment & \multicolumn{1}{|c|}{ Remarks } & \multicolumn{1}{c|}{$\mathrm{B}$} & \multicolumn{1}{c|}{ Wald } & \multicolumn{1}{c|}{ Sig. } & \multicolumn{1}{|c|}{$\operatorname{Exp(B)}$} \\
\hline \multirow{4}{*}{ Mosque } & Intercept & 20,784 & 249,786 &, 000 & \\
\cline { 2 - 7 } & {$[\mathrm{PZ}=0]$} & $-3,771$ & 7,832 &, 005 &, 023 \\
\cline { 2 - 7 } & {$[\mathrm{PZ}=1]$} & $0(\mathrm{~b})$ &. &. & \\
\cline { 2 - 7 } & {$[\mathrm{SURE}=0]$} & 4,089 & 9,263 &, 002 & 59,666 \\
\cline { 2 - 6 } & {$[\mathrm{SURE}=1]$} & $-19,696$ & 641,556 & .000 & $2,79 \mathrm{E}-009$ \\
\cline { 2 - 6 } & {$[\mathrm{KPS}=0]$} & $0(\mathrm{~b})$ &. &. & \\
\cline { 2 - 6 } & {$[\mathrm{KPS}=1]$} &. &. & \\
\hline
\end{tabular}

Source: SPSS-based primary Data Process

The Probability of Digital Zakat Use by Muzaki

In terms of this equation, if all variables are zero (0), referring to group of less zakat knowledge and no certainty of using digital zakat method, the following equation will be obtained:

$$
\begin{array}{ll}
\operatorname{Ln}(\mathrm{P} 1 / \mathrm{P} 0) & =20,784 \\
(\mathrm{P} 1 / \mathrm{P} 0) & =\operatorname{Exp}(20,784) \\
(\mathrm{P} 1 / \mathrm{P} 0) & =1062616394 \\
\mathrm{P} 1 & =1062616394 \mathrm{P} 0
\end{array}
$$

which means insufficient chance for muzaki to obtain zakat knowledge and therefore not sure of the benefits of zakat with no good of worship level due to indiscpline zakat payment through the mosque 1062616394 times bigger than chance to pay zakat via BAZ / LAZ.

Then value 0 was inserted in the second equation which the following equation is indicated as follows:

$$
\begin{array}{ll}
\operatorname{Ln}(\mathrm{P} 2 / \mathrm{P} 0) & =20,430 \\
(\mathrm{P} 2 / \mathrm{P} 0) & =\operatorname{Exp}(20,430) \\
(\mathrm{P} 2 / \mathrm{P} 0) & =565823746.8 \\
\mathrm{P} 2 & =565823746,8 \mathrm{P} 0
\end{array}
$$

which means that muzaki with less digital zakat knowledge are not sure of digital zakat that they make a direct zakat. The value is higher than that of zakat made digitally with 565823746.8 times. 
Table 6. Reasons of No Use of Digital Zakat by Muzaki

\begin{tabular}{|l|c|c|}
\hline \multicolumn{1}{|c|}{ Reasons of Payment } & \multicolumn{2}{c|}{ Knowledge of Zakat } \\
\cline { 2 - 3 } & Yes & No \\
\hline $\begin{array}{l}\text { Not well-informed of } \\
\text { Digital Zakat }\end{array}$ & $29.2 \%$ & $71 \%$ \\
\hline No Trust in Digital Zakat & $70 \%$ & $29.1 \%$ \\
\hline $\begin{array}{l}\text { No satisfaction of the use of online Zakat } \\
\text { payment }\end{array}$ & $88 \%$ & $12 \%$ \\
\hline
\end{tabular}

Source: SPSS-based primary Data Process

According to the study, in terms of knowledge of digital zakat, $70,8 \%$ of Muzaki have no sufficient information about digital zakat, and they thus did not use digital zakat. Though $90 \%$ of them have social media accounts, they never notice digital zakat advertisement. Whereas, in terms of

\section{REFERENCES}

Daud, Z. et.al. (2011). Model Perilaku Kepatuhan Zakat: Suatu Pendekatan Teori. Jurnal Iqtishoduna. Vol. 7, No. 1: 1-21.

Jahrotu Nasipah, I. (2012). Faktor-Faktor Yang Mempengaruhi Keputusan Pegawai Negeri Sipil (PNS) Di Lingkungan Pemerintah Daerah Kota Cirebon Untuk Membayar Zakat Profesi Melalui BAZ / LAZ Dengan Cara Pemotongan Gaji. http://ekospasca.blogspot.com/201 2/12/faktor-faktor-yangmemengaruhi. html. Accessed in September 102018.

Jamila. 2018. Analisis Efisiensi \& Efektivitas Zakat Payroll System Dan Zakat Digital Terhadap Penerimaan Zakat Pada Baznas Periode 2016-2017. 2018. Jakarta. Diakses di https:// repository.uinjkt.ac.id. $\quad 10$ September 2018

Kotler,P. \& Armstrong, G. 2009. Principles of Marketing. Pearson Education. Thirteenth Edition. New Jersey. knowledge of zakat, $65,1 \%$ of those with good knowledge of zakat use direct payment, 25,6\% use others, 2,3\% have no trust in BAZ/LAZ and 7\% not well-informed with BAZ/LAZ. For further information, the following table will show as follows:

Kotler, P. (2005). Manajemen Pemasaran. Edisi kesebelas. Jakarta: Indeks

Marlina E. (2014). Understanding Behavior in Selection of Zakat Methods: a Analysis of Muzakki in Malang City, Indonesia Paper is presented at International Conference on Islamic Economics and Civilization (ICIEC 2014). 5 June 2014, Surabaya, Indonesia

Merlinda, S. 2016. The Determinant Of Moslem's Decision In Performing Commerce Zakat Payment: Case Study In Malang City, East Java Province. International Journal of Social and Local Economic Governance (IJLEG). Vol. 2, No. 1, April 2016, pages 59-68

Muhammad-Bashir Owolabi Yusuf. 2013. Measurement model of corporate zakat collection in Malaysia: A test of diffusion on innovation theory. Malysia. Accessed in September 102018

Nurul Nadiah Ahmad, Mahlindayu Tarmidi, Izzatul Ussna Ridzwan, Masdiah Abdul Hamid, Rusli Abdul Ronidari Universiti Tenaga 
Nasional, Malaysia. 2014. The Application of Unified Theory of Acceptance and Use of Technology (UTAUT) for Predicting the Usage of E-Zakat Online System. Malyasia. International Journal of Science and Research (IJSR) ISSN (Online): 2319-7064 Tahun 2014. Accessed in September 102018

Nurhayati, Siswantoro. 2012. Factors affecting concern about zakat as a tax deduction in Indonesia

Sari, Dian Silvia Arda. (2010, Maret 06). Zakat dan Organisasi Pengelola Zakat.

(http://ariefhilmanarda.wordpress.c om/2010/03/06/zakat-dan organisasi- pengelola-zakat

Siska, Siswantoro. 2012. Analysis of zakat on income payers' preference in Indonesia (Potency of double zakat).

Suprayogi, Agung. 2011. Faktor-Faktor Yang Mempengaruhi Keinginan Dan Preferensi Pengusaha Mikro Untuk Berzakat. Skripsi. Universitas Indonesia. . Accessed in September 102018

Uzaifah. (2007). Studi Deskriptif Perilaku Dosen Perguruan Tinggi Islam DIY dalam Membayar Zakat. Jurnal La Riba (Jurnal Ekonomi Islam) 1(1) (Juli 2007): 17. Diakses dari http://journal.uii.ac.id/index.php/J EI/article/view/1051/976 pada 8 September 2018.

Wiradani, Windi. 2012. Faktor-faktor yang dipertimbangkan muzakki dalam menyalurkan zakat melalui

Yayasan Amal Sosial Ash Shohwah Malang. Malang. Diakses dari https://ibrary.um.ac.id pada 8 September 2018.
Deasy Tantriana

State Islamic University of Sunan Ampel

Surabaya

Indonesia

Lilik Rahmawati

State Islamic University of Sunan Ampel Surabaya

Indonesia 